\title{
A Teacher's Practical Knowledge in an SSI-STEAM Program Dealing with Climate Change
}

\author{
A-Rang Won \\ Department of Science Education, Seoul National University, o8826 Seoul, \\ Republic of Korea \\ arang89@gmail.com
}

Su-Yeon Choi | ORCID: 0000-0002-6280-3445

Department of Science Education, Seoul National University, o8826 Seoul, Republic of Korea

csy222@snu.ac.kr

Hye-Eun Chu | ORCID: 0000-0001-8937-1446

School of Education, Macquarie University, Sydney, NSw 2109, Australia hyeeun.chu@gmail.com

\section{Hyun-Jung Cha}

Department of Science Education, Seoul National University, o8826 Seoul, Republic of Korea

toddogo6@snu.ac.kr

\section{Hyeonjeong Shin}

Department of Science Education, Seoul National University, o8826 Seoul, Republic of Korea

masic12@snu.ac.kr

\section{Chan-Jong Kim}

Corresponding author,

Department of Earth Science Education, Seoul National University, o8826

Seoul, Republic of Korea

chajokim@snu.ac.kr

Received:18 March 2021 | Revised: 29 April 2021 |Accepted: 1 May 2021 


\begin{abstract}
Teachers do not simply deliver a set curriculum, but carry out classes based on practical knowledge, including their values, beliefs, and experiences. Therefore, it is meaningful to investigate the practical knowledge of teaching among teachers in terms of orientation, structure, and content in order to understand the teacher's knowledge, conflicts, and trial and error experiences in the classroom. In this study, we explored the practical knowledge of a teacher conducting SSI-STEAM classes themed on climate change. In the specific context of SSI-STEAM classes, it was possible to understand how the teacher organized climate change classes and guided the actions of students in action-oriented classes. In addition, we expect that this study, which examines the practical knowledge of a novice teacher, will serve as the first step in narrowing the gap in SSI-STEAM education between pre-service teacher education and actual school classroom experience.
\end{abstract}

\title{
Keywords
}

practical knowledge - science teacher - climate change - SSI-STEAM class

\section{초록}

교사는 정해진 교과 내용을 단순히 전달하는 것이 아니라 자신의 가치관, 신념, 상황 및 경험에 의해 구성된 실천적 지식에 근거하여 수업을 실행해 나간다. 따라서 수업을 실행하는 교사의 실천적 지식을 정향, 구조, 내용의 측면에서 살펴보는 것은 수업에 반영된 교사의 지식, 갈등 및 시행착오에 대하여 심층적으로 이해할 수 있다는데 의의가 있다. 본 연구에서는 기후변 화를 주제로SSI-STEAM 수업을 실행하는 교사의 실천적 지식을 분석하였다. 이를 통해SSI-STEAM 수업이란 특정 맥락에서 교사가 기후변화 수업을 어떻 게 구성하고, 실천 지향의 수업에서 학생들의 어떠한 행동을 이끌어내는지 살펴볼 수 있었다. 더불어 교직 전반에 대한 이미지를 만들고 결정적 시기 라 할수 있는 초임교사의 실천적 지식을 살펴본 이 연구가SSI-STEAM 교육 을 위한 교사교육과 학교현장 사이의 간극을 줄이는데 단초가 될 것이라는 기대와 시사점을 논하였다.

\section{Introduction}

The Intergovernmental Panel on Climate Change (IPCC, 2014) reported a clear human impact on the climate system in its fifth evaluation report and approved 
the special report Global Warming of $1.5^{\circ} \mathrm{C}$ in 2018 that said the Earth's temperature rise should be kept within $1.5^{\circ} \mathrm{C}$ by 2100 . Climate change is one of the 'manufactured risks' (Giddens, 2009) caused by modernization via science and technology (Beck, 1997). As climate change has emerged as an urgent global risk, global citizens should be equipped with a sense of commitment to community and responsible behavior to reduce the causes of climate change.

Science education should play an important role for preparing people to cope with climate change, because understanding and resolving climate change require scientifically informed decisions and actions. Recently, the use of socio-scientific issues (SSI) education in science education has received attention. ssis are reality-based controversial issues that require students to make moral judgments and take action as democratic citizens, beyond the mere learning of scientific knowledge (Zeidler \& Nicols, 2009). Covering these issues in science classes involves students in seeking solutions to unstructured problem situations from various perspectives or arguing situations with no correct answers. Therefore, ssi education has an inter-disciplinary form that is intricately linked to many fields beyond science (Sadler \& Zeidler, 2005). Climate change, which has been regarded as one of the major themes of SsI education, is inter-disciplinary in nature, as are many other ssi topics, and fuses diverse areas and perspectives such as science, technology, society, and the humanities. Therefore, Science Technology Engineer Arts Mathematics (STEAM) approaches could be highly applicable to ssi education and climate change education because of their ability to help students understand the challenges related to the many areas involved and find solutions that take them into account. STEAM education has been supported by researchers in sSI education over STEM education (Zeidler, 2016) because SSI is as unavoidably associated with liberal and fine arts. STEAM education based on ssis can provide students with rich real-world case studies and allows them to engage in controversial topics confronting their own society (Johnson, Macalalag, \& Dunphy, 2020) as well as exploring a variety of academic areas. In this context, we suggest an SSI-STEAM education approach for climate change education, which has characteristics of both the SSI and STEAM education approaches.

SSI-STEAM climate change education includes understanding the science of climate change; the impacts of climate change; various approaches to resolution of the issue at the individual, social, international levels; and preparing and taking action. This is substantially different from traditional science classroom education. As such, it is anticipated to invoke many new challenges in learning and to necessitate new guidelines for participants, including students and teachers. Many teachers have been reported having difficulty with ssi education contexts. Even though most science teachers are aware of the need to 
introduce ssis in classes and have responded positively to their educational effects (Choi, Cho, \& Kim, 2000; Lee \& Jang, 2011; Yang et al., 2012), few teachers have introduced ssi education in their classes (Lee \& Witz, 2009) because of their adherence to traditional teaching methods, lack of class hours, lack of ssi teaching materials, and university entrance-oriented school culture (Cross \& Price, 1996; Lee, Abd-El-Khalick, \& Choi, 2006). Teachers who wanted to introduce STEAM approaches in their classrooms also had difficulties such as the associated decrease in science content, difficulties in preparing students for college entrance exams, and difficulties with the selection of integrated topics (Kim \& Lee, 2015; Son \& Jung, 2019). The SSI-STEAM education approach can pose more complicated and difficult challenges to teachers. As SSI-STEAM climate change education is urgent and important, it is critical to understand how teachers manage to meet and resolve the difficulties encountered during the implementation of an SSI-STEAM program by using their practical knowledge.

\section{Theoretical Background}

Although pedagogical content knowledge (PCK) has been one of the most investigated perspectives for teacher professional knowledge, the results have had little impact on teacher education (Kind, 2009), and its potential has not been fully recognized (Nilsson \& Vikstrom, 2015; Schneider \& Plasman, 2011). We chose teachers' practical knowledge as a theoretical lens to understand their practice in the SSI-STEAM education classroom. Practical knowledge is the knowledge in which teachers themselves reconstruct their own knowledge based on their values and beliefs (Elbaz, 1981, 1983) and is the core of teachers' expertise in determining teaching practice (Van Driel, Beijaard, \& Verloop, 2001). Elbaz (1981, 1983), who conceptualized teachers' practical knowledge, proposed to view practical knowledge as comprising three aspects - orientation, content, and structure - in order to refine the kinds of knowledge teachers utilize. Orientation is the source of practical knowledge, the fundamental background of teaching. The structure of practical knowledge plays a key role in identifying what practical knowledge is in the actual class situation, and it can be broken down into the rules, principles, and images, depending on the degree of generalization (Elbaz, 1981, 1983). The content that constitutes practical knowledge functions as a specific aspect of creating a class, but it is formed and revealed in the orientation of practical knowledge. In the end, the class, which is revealed by the combination of content and orientation, is expressed as a unique structure for each teacher. 
Practical knowledge is known as integrated knowledge: theoretical knowledge; everyday knowledge, including norms and values; and experiential knowledge (Handal \& Lauvas, 1987). The process of knowledge integration is guided by experiences that play a key role in the development or change of teachers' practical knowledge. Connelly, Clandinin, and He (1997) pointed out that a teacher's practical knowledge resides in the teacher's experience (their own school history), in the teacher's present mind and body (e.g., based on their level of educational achievement), and in their future plans and actions. In this sense, Ratinen et al. (2015) argued that even novice student teachers without longer teaching experience have some practical knowledge, based on their own history, and so the authors investigated these novices' practical knowledge. Therefore, we can assume that new teachers also have practical knowledge from their learning during pre-service education in college and from their experiences as students and as teachers in schools.

The major goal of this study was to investigate new teachers' practical knowledge when teaching an SSI-STEAM education program which is new and unfamiliar to them. To investigate new teachers' practical knowledge, we aimed to use Elbaz's (1981) perspectives of practical knowledge. The teachers' teaching practice during the SSI-STEAM climate change education program was explored with three aspects of Elbaz's theory of practical knowledge: orientation, structure, and content. The major conflicts that teachers experienced and the practical knowledge they used to resolve conflicts throughout the program were also identified.

\section{3}

\section{Research Questions}

Two research questions were formulated to achieve the study's major goals:

(1) What is the practical knowledge (orientation, structure and content) of a new teacher who teaches in an SSI-STEAM climate change education program?

(2) What conflicts does the teacher experience while teaching the SSI-STEAM climate change education program, and what practical knowledge does the teacher use to solve them?

\section{$4 \quad$ Method}

\subsection{Research Procedure}

This study aimed at understanding a teacher's practical knowledge in the new context of an SSI-STEAM education program on climate change. A single case 


\section{Literature Review}

\section{Conducting Pre-interview}

\section{Climate Change SSI-STEAM Program Implementation}

\section{Conducting Post-interview}

\section{Data Analysis}

FIGURE 1 Research procedure

study method was adopted. The study was conducted following the procedure in Figure 1. After the literature review, an initial SSI-STEAM education program was developed by researchers. It was collaboratively revised with the participating teacher and the final program was completed and implemented. Interviews were conducted before and after the program. The teacher also provided reflections on his teaching after the program. During the program, classes were videotape-recorded, and the teacher's teaching materials were also collected.

\subsection{Research Participant and Research Context}

To achieve the goals of the study, purpose sampling was conducted. Major criteria of sampling were the ability to explain one's own thought processes well and willingness to teach new themes and methods. We searched for a participant by recommendation and were able to find a teacher with the following characteristics: abundant enthusiasm for teaching science classes, and little fear of teaching new themes in novel ways. He proactively expressed his willingness to participate in the study.

The teacher who participated was in his first year of teaching and 26 years old. He had a B.Ed. Degree in Physics Education together with a secondary school science and physics teaching certificate. He had dreamed of becoming 
a teacher from his high school days while teaching mathematics to students with developmental disabilities at a welfare center for two years. To realize his dream of becoming a teacher, he enrolled in the local college of education and later joined an education volunteers' club providing extra education to adolescents in underprivileged areas. Before graduation, he was active enough to be elected as the president of this club. He taught a variety of subjects, including music, English, and mathematics, though not science, in the club classes, which gave him the opportunity to develop his capability to teach in several different ways, to teach non-major subjects, and to integrate different subjects. Researchers could feel his passion for the club classes during interviews where he described his happy memories about the club classes, his preparation for the classes often taking him all night. He also stated that the experience was of great help to him in his career as a schoolteacher. He had a positive perception of the curriculum convergence class, knowing that fusing different subjects under one topic helps students understand the topic better, and that approaching the learning subject in a wide range of ways can open up a wider range of thinking and a greater variety of career perspectives to the students.

This teacher was trying to emphasize the joy of studying science to male students because he thought that female students tended to study harder and performed better than male students at school. He also tried to make the written test as easy as possible so that students would not feel that studying science was too heavy a burden.

The school where the teacher worked was a public junior high school located in the south-eastern part of Seoul. This district is popular among parents, with a strong reputation for academic achievement. According to the results of the Korean National Academic Assessments, students in the school have demonstrated an exceedingly high level of academic performance. Parents in the area are very interested in the students' academic work and some even send their children to private 'cramming' or tuition schools.

The SSI-STEAM education program on climate change was implemented in an eighth-grade class displaying a good attitude to science classes. The class size is about 31 students. The program was implemented in the usual science classes, after the final exam: from 6-20 December 2019, with a total of seven classes (45 minutes per class). The study was planned as an international comparison study between Korea and Australia. However, because of the CoviD-19 pandemic, the study was conducted in Korea only, except for the first online 'greet and meet' session between students in the two countries, convened to discuss climate change. 


\subsection{Development, Reorganization, and Implementation of SSI-STEAM Climate Change Education Program}

The SSI-STEAM climate change education program was first developed by the researchers and revised collaboratively with the participant teacher. The initial program was developed by the researchers with the goals of helping students to search for resolutions and fostering their competence to take action based on scientific understanding of climate change and its impacts in global contexts. The program also emphasized social action to reduce greenhouse gases and mitigate climate change through the convergence of various disciplines related to climate change resolution, and it provided opportunities for students to become active participants in social action. The initial program had three steps, piloted with six classes: (1) understanding climate change and its impacts, (2) developing action plans and (3) social action (Figure 2). In Step 1, Korean students in the program were supposed to conduct video conferencing with Australian students and to explore changes in global climate change dynamics, using satellite data. In Step 2, scientific inquiry activity on climate

\section{Step 1 : Understanding climate change and its impacts \\ $1^{\text {st }}$ class : Video conferencing with Australian students on climate change issue \\ $2^{\text {nd }}$ class : Exploring the impacts of climate change using satellite data on major continents}

Step 2 : Developing individual action plans

$3^{\text {rd }}$ class : Understanding the science of climate change

$4^{\text {th }}$ class : Developing action plans for small groups

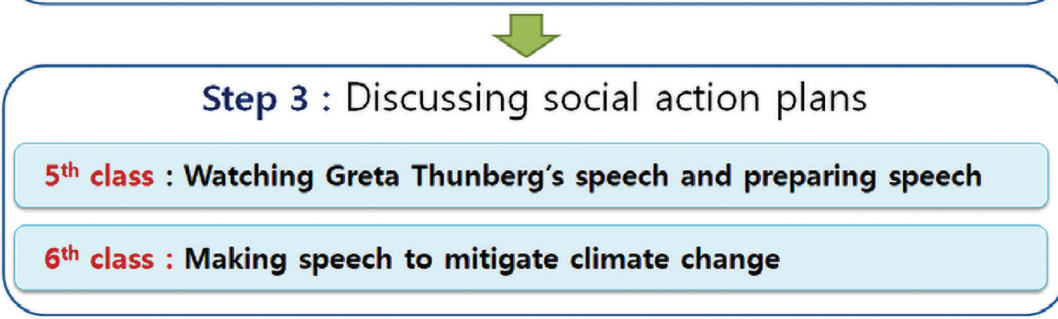

FIgURE 2 The initial sSi-STEAm Education Program for climate change developed by researchers 
change, and small group action plan development were included. In Step 3, students prepared and delivered speeches about social action for climate change mitigation, after watching Greta Thunberg's speech.

Through collaboration with the participant teacher in this study, the initial program was revised. The teacher proposed some changes in the program based on his beliefs, knowledge, and the school context. The teacher suggested adding one more class hour to secure enough time for students' activities. As a result, the program had seven classes. 'The tragedy of the commons' concept concerning individual greed versus community needs was also included for discussion in the fourth class. In Step 3, writing and presenting speech activities were replaced by developing and posting climate crisis stickers. The final SSI-STEAM climate change education program also features three steps (Figure 3). The overall structure of the program consists of aspects of ssi education, scientific understanding, searching for resolution, and social action. The program also includes multiple STEAM areas, especially in the fourth class, and introduces a topic from social studies, i.e., looking at 'the tragedy of the commons' and integrating this issue with the climate change crisis. The

Step 1 : Understanding climate crisis and its impacts

$1^{\text {st }}$ class : Video conferencing with Australian students on climate change issue

$2^{\text {nd }}$ class : Exploring the impacts of climate change using satellite data on major continents

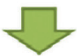

Step 2 : Searching for resolution of climate crisis

$3^{\text {rd }}$ class : Understanding the science of climate crisis

$4^{\text {th }}$ class : Watching 'The tragedy of the commons' and discussing resolutions and action plans for climate crisis

Step 3 : Social action for climate crisis

$5^{\text {th }}$ and $6^{\text {th }}$ class : Designing and developing climate crisis sticker

$7^{\text {th }}$ class : Presenting where posted climate crisis sticker

FIGURE 3 The climate change program revised with the teacher 
climate crisis sticker design in Step 3 also has STEAm aspects. Students are asked to complete a sticker planning sheet in the fifth class. When designing a sticker each student needs to consider symbolism, simplicity, attraction, and the creativity of the sticker. In Step 3, students got opportunities to experience three criteria of STEAM learning: context presentation, creative design, and the emotional touch (KOFAC, 2018).

Data Collection and Analysis

\subsection{Data Collection}

Data was collected by interviews, and video and audio recordings, during the program. Teaching materials (PowerPoint [РPT], videos, worksheets, and flash files), and the teacher's class reviews were also collected. In-depth interviews were conducted with the teacher once before class and twice after class. After the post-program interview, two additional interviews were conducted using e-mails to collect supplementary information. Second, the video camera was installed in the classroom to film the entire course of the program, and the teacher's voice was also audio-recorded. Third, after the whole program was over, the teacher wrote class reviews. The class video recordings and interview results were all transcribed and analyzed.

\subsection{Data Analysis}

Analysis of the data was conducted according to the constant comparison method, to explore the teacher's practical knowledge (Merriam, 1998). First, interview transcriptions were read repeatedly. Afterwards, open coding was conducted based on the dominant patterns revealed. Open coding was conducted as a line-by-line analysis of the interview transcripts. The parts appropriate to the definition of practical knowledge were identified and underlined in sentences. Each of these parts was named with an in vivo code that directly cited teacher statements and an explanatory code that summarized the basic subject of qualitative data in a single word or short section. In this process, the characteristic elements of practical knowledge that were repeated in classes and interviews were identified.

The teacher's practical knowledge identified in the open coding was categorized into three aspects: orientation, content and structure. Orientation is the foundation of practical knowledge, and the fundamental background of teaching (Elbaz, 1983). Practical knowledge related to the direction of teaching, decision-making, and personal beliefs about teaching was categorized as orientation, and was subdivided into five domains: situational, personal, social, 


\begin{tabular}{|c|c|c|}
\hline Orientation & Definition & Code \\
\hline Situational & $\begin{array}{l}\text { Influenced by the context of the } \\
\text { particular situation the teacher is in. }\end{array}$ & A special event \\
\hline Personal & $\begin{array}{l}\text { Influenced by the feelings, sense of } \\
\text { purpose, and values of an individual } \\
\text { teacher }\end{array}$ & Values and mindset \\
\hline Social & $\begin{array}{l}\text { Influenced by the social environment } \\
\text { surrounding teachers }\end{array}$ & $\begin{array}{l}\text { Education policy, } \\
\text { parents, managers, social } \\
\text { trends }\end{array}$ \\
\hline Experiential & $\begin{array}{l}\text { Influenced by the personal experience } \\
\text { of a teacher }\end{array}$ & Steady experience \\
\hline Theoretical & $\begin{array}{l}\text { Influenced by various theories or } \\
\text { research }\end{array}$ & $\begin{array}{l}\text { Theoretical knowledge, } \\
\text { reading, graduate school. }\end{array}$ \\
\hline
\end{tabular}

experiential, and theoretical orientation. The framework for orientation was constructed based on the categories and definitions of Elbaz $(1981,1983)$ and the code for analysis (Table 1) was derived from the teacher interview materials based on Kim and Lee (2015).

From the results of open coding, knowledge about the foundation of teaching was identified as the content aspect of practical knowledge. The framework for content was constructed based on the four categories and definitions of Elbaz (1981, 1983): self-knowledge, curriculum and subject matter knowledge, instruction knowledge, and school milieu knowledge. The codes were developed from the teacher's interview data, based on the results of previous studies (Lee \& Witz, 2009; Kim \& Hong, 2017). In each sub-category of content, four or five codes were included (Table 2), making it easier to identify the subcategories of content in the results of the open coding.

The structure of practical knowledge can be detailed into the rule of practice, practical principles, and image depending on the degree of generalization (Elbaz, 1981; 1983). The structure can be understood as vertical, while orientation and content are horizontal. The categories and definitions of structure (Elbaz, 1981;1983) were used as a framework for analyzing the structure of practical knowledge, as shown in Table 3. Image is the most comprehensive statement that guides the direction of teaching practice. The simplest and clearest statement of what to do or how to do in a particular situation is a rule. A principle is a statement that is between images and rules in terms of generalization. 
TABLE 2 Framework for content analysis

\begin{tabular}{|c|c|c|}
\hline Content & Definition & Code \\
\hline Self-knowledge & $\begin{array}{l}\text { Knowledge of the teacher's own } \\
\text { value and purpose, knowledge of } \\
\text { how he sees himself as a teacher } \\
\text { and what role he defines for } \\
\text { himself }\end{array}$ & $\begin{array}{l}\text { - Values } \\
\text { - A sense of purpose } \\
\text { - A new attempt } \\
\text { - Self-awareness } \\
\text { - Experiential conflicts and } \\
\quad \text { difficulties }\end{array}$ \\
\hline $\begin{array}{l}\text { Curriculum and } \\
\text { subject matter } \\
\text { knowledge }\end{array}$ & $\begin{array}{l}\text { Knowledge of understanding and } \\
\text { reorganizing the curriculum, and } \\
\text { of the expertise that teachers } \\
\text { transfer to learners through the } \\
\text { curriculum }\end{array}$ & $\begin{array}{l}\text { - Understand the subject } \\
\text { matter } \\
\text { - } \text { Perception of subject matter } \\
\text { - } \text { Understanding the } \\
\text { curriculum } \\
\text { - } \text { Knowledge about curriculum } \\
\text { reorganization }\end{array}$ \\
\hline $\begin{array}{l}\text { Instruction } \\
\text { knowledge }\end{array}$ & $\begin{array}{l}\text { Knowledge related to the } \\
\text { understanding of the meaning of } \\
\text { learning and the understanding } \\
\text { of learners }\end{array}$ & $\begin{aligned} \text { - } & \text { Meaning of learning } \\
\text { - } & \text { Interacting with students } \\
\text { - } & \text { Understanding of learners } \\
\text { - } & \text { Understanding of each } \\
& \text { student } \\
- & \text { Teaching knowledge }\end{aligned}$ \\
\hline $\begin{array}{l}\text { School milieu } \\
\text { knowledge }\end{array}$ & $\begin{array}{l}\text { Understanding of the social, } \\
\text { political, economic, cultural, and } \\
\text { geographical environment } \\
\text { surrounding classrooms and } \\
\text { schools to which teachers } \\
\text { belong }\end{array}$ & $\begin{array}{l}\text { - Class and school situation } \\
\text { knowledge } \\
\text { - Knowledge of the physical } \\
\text { environment of schools } \\
\text { - An understanding of the } \\
\text { social, political and regional } \\
\text { environment } \\
\text { - Psychological knowledge of } \\
\text { the environment, } \\
\text { managers, fellow teachers, } \\
\text { and parents. }\end{array}$ \\
\hline
\end{tabular}

Principles are intentional for understanding teachers' deliberation and for reflecting on teaching behaviors that teachers take for granted. The open coding data were reviewed and the teacher's practical knowledge at image level was identified first, after which, the analysis proceeded to principles and rules 
TABLE 3 The structure of the CLQ

\begin{tabular}{lllll}
\hline Domain & Sub-domain & $\begin{array}{l}\text { Number } \\
\text { of items }\end{array}$ & Question number & $\begin{array}{l}\text { Question } \\
\text { type }\end{array}$ \\
\hline Knowledge & Causes & 8 & $1-8$ & True/false \\
& Impacts & 8 & $9-16$ & \\
Perception & Susceptibility & 3 & $2,7,15$ & Likert \\
& Issue recognition & 7 & $3-5,11-14$ & scale \\
& Attitudes toward choice & 3 & $1,8,16$ & \\
& Control point & 3 & $6,9,10$ & \\
& & & & $1,3-6,10,11,13,14$ \\
Action & Individual & 9 & $2,7-9,12,15,16$ &
\end{tabular}

Background questions (12) requiring a written response format were provided with the CLQ.

Total 48 CLQ questions and 12 Background questions

levels. Finally, comparing and analyzing the practical knowledge analyzed with the raw materials was intended to create a new meaning for the relationships or conflicts between the categories of practical knowledge.

\subsection{Trustworthiness}

In order to improve the validity and reliability of the findings as a qualitative single-case study, this study sought to collect and analyze the research data, taking into account specific strategies to enhance the reliability of Lincoln and Guba (1985) and Merriam (2009). First, for triangulation, data from several sources were collected and compared. The error of interpretation was reduced by comparing and analyzing data collected in various ways, such as in-depth interview data, class videos, the teacher's class material (PPT, video, worksheets, flash file) and the teacher's class review.

Second, the results of the study were reported to the participant teacher and were checked by him for credibility. Third, the results of the analysis were reported to and reviewed by a group of science education experts five times. 
The science education experts consisted of one science education professor and 10 graduate students. The adequacy of the analysis was discussed during the group reviews.

\section{$6 \quad$ Results}

6.1 The Teacher's Practical Knowledge in SSI-STEAM Education Program In this section, we share findings related to content and structure.

6.1.1 Content and Structure

6.1.1.1 Images, Principles, and Rules about a Teacher Himself

The most comprehensive image of oneself that the teacher revealed throughout the program was as a 'Guide'. This description appeared several times during the interviews.

The role of a teacher in the class seems to be a strong guide. It's because teachers' biggest task is to focus on classes, to present topics, and to invite them to the learning field. [2nd Post-program interview]

I think it should be our mindset that must precede the implementation of the national curriculum. Even if the national curriculum emphasizes the importance of climate change, it would not be enacted in the classroom if teachers have no empathy for it. [2nd Post-program interview]

The image of 'a guide' is also related to the chief goal of climate change classes, which is to encourage students to take action. The participant teacher in this study thought that if students were not aware of the enormous impact of climate change, then even if regulations were imposed to mitigate climate change, this would hardly lead to action. Therefore, beyond scientific knowledge, the role of a teacher-guide has become important to help students realize the seriousness of climate change, seek action measures, and put them into action.

Three principles were identified as desirable for the teacher to apply to himself (Table 4). The first principle for the teacher as guide is, 'Encourage students to empathize about the seriousness of climate change'. Since the topic of climate change was not included in the normal science curriculum in the junior high school, the program was implemented after the final exam of the 
TABLE 4 Images, principles, and rules about a teacher himself

Images (about a teacher himself): A Guide

\begin{tabular}{|c|c|}
\hline Principle 1 & Empathize the seriousness of climate change \\
\hline Rules & $\begin{array}{l}\text { - Provide various data indicating the seriousness of climate } \\
\text { change when introducing classes. } \\
\text { - Utilize activities to identify the seriousness of climate change }\end{array}$ \\
\hline Principle 2 & Make students interested in class. \\
\hline Rules & $\begin{array}{l}\text { - Introduce quiz games that attract students' attention. } \\
\text { - Utilize video clips and simulation materials. }\end{array}$ \\
\hline Principle 3 & Provide reliable information. \\
\hline Rules & $\begin{array}{l}\text { - Inform the source of the class materials. } \\
\text { - Fill in the source of the photos and graphs provided. }\end{array}$ \\
\hline
\end{tabular}

school year. This gave the teacher some freedom to introduce the topic and to invite students to immerse themselves in the action-oriented climate change education program.

I think the role of a teacher is most important in the introduction of the climate change class that I prepared. It's because students have to be aware that the problem is serious, so that future classes can proceed based on awareness. [2nd Post-program interview]

Two more specific rules related to Principle 1 were identified. The teacher thought that students could further develop their willingness to mitigate climate change if they realized the seriousness of climate change and the damage directly attributable to it. This principle is embodied in the rules, 'The teacher provided various data indicating the seriousness of climate change when introducing classes and 'Students do activities to identify the seriousness of climate change on their own'. The teacher prepared and provided data including graphics (Figure 4) and reports (Figure 5) showing the seriousness of and the damage caused by climate change. (Figures 4,5 ).

The second principle of the teacher as guide is 'Make students interested in classes'. The teacher proposed to replace the climate change speech-writing activity in the initial program with a climate crisis stickers activity. The reason for the replacement was to allow students to get interested in and participate in the class. He emphasized students' interest and their immersion in the class because the goal of the class was to establish the students' own action plans for 

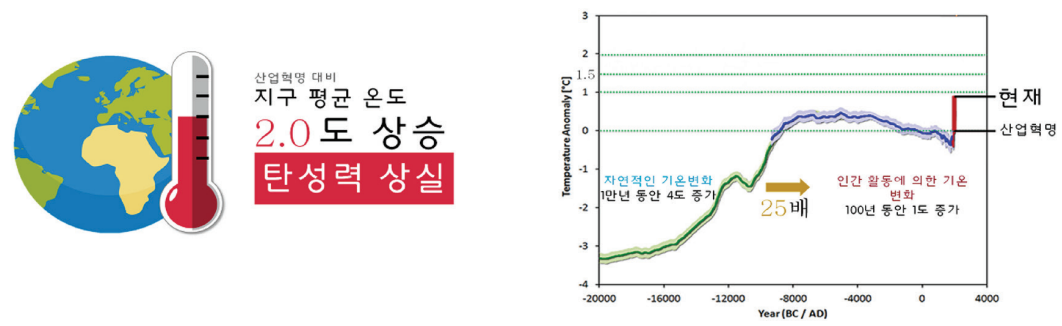

FIGURE 4 Teacher PPT to guide the seriousness of climate change. (a) Loss of temperature elasticity due to rising average temperature on Earth, (b) Earth's Average Temperature Variation Graph

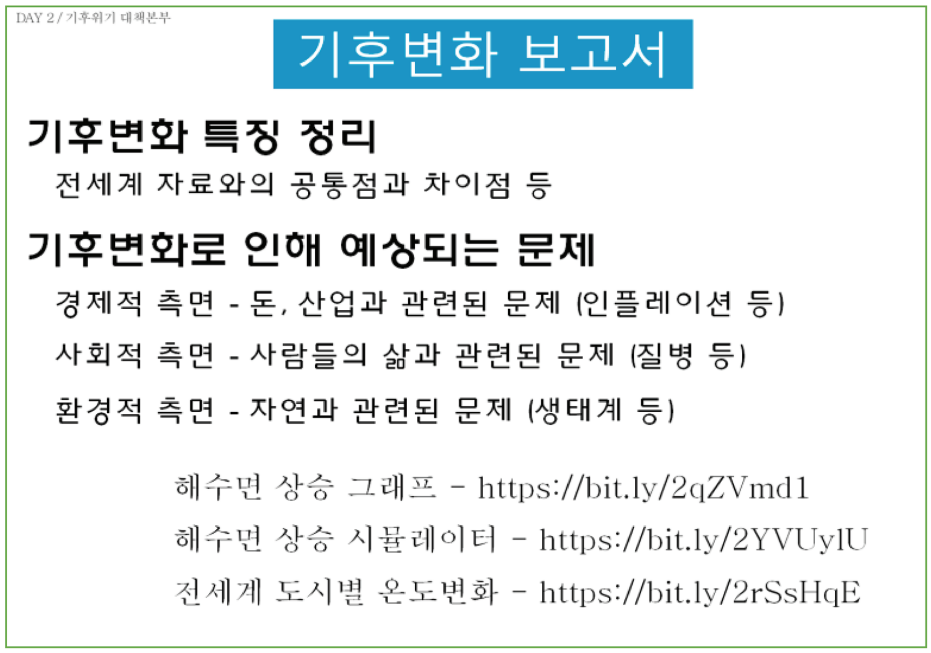

\section{Climate Change Report}

\section{Summary of climate change characteristics of the region}

- Commonalities and differences with global data

\section{Problems anticipated by climate change}

- Economic aspects - Problems with money, industry (inflation, etc.)

- Social aspects - Problems related to people's life (disease, etc.)

- Environmental aspects - Problems related to nature - (ecosystem, etc.)

Sea level rise graph - http/bit.ly/2qZVmdl

Sea level rise simulator - https: //bit.ly/2YVL yl1

Temperature changes of major cities of the world - https://bit.ly/2rSsHqE

FIGURE 5 Teacher's PPT to guide activities of the Climate Change Counter-measure Headquarters ( $\mathrm{CCCH})$ (Korean and English translation) 

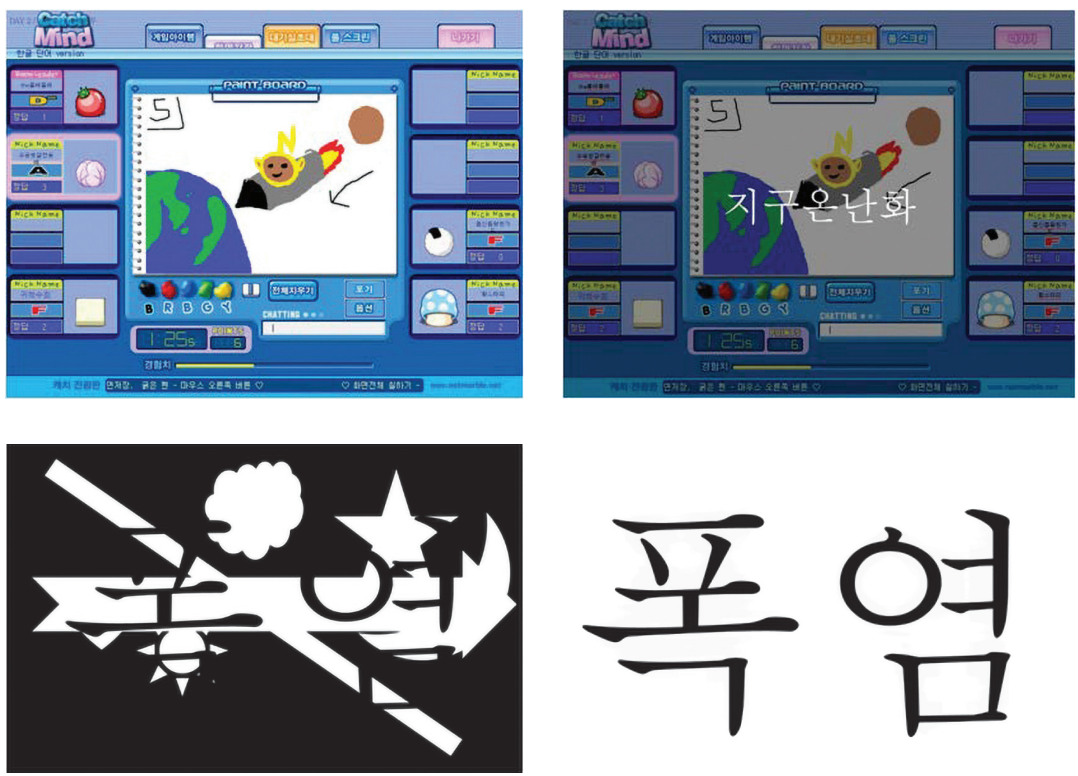

FIGURE 6 Teacher's PPT of quiz game

climate change mitigation, followed by concrete action. The second principle is embodied in the rule, 'Introduce quiz games that attract students' attention' and 'Use video and simulation materials'. The participant teacher prepared a quiz and PPT slides that required students to guess what words were hidden in them (Figure 6).

The final principle derived from the image of the teacher as guide concept was 'Providing reliable information'. For a science teacher, providing scientific and reliable information is an important aspect of their role as a guide.

The most important thing for a teacher is literacy, clarifying the source, delivering information that the teacher can trust. I've spent most of my time on it. [1st Post-program interview]

\subsubsection{Images, Principles, and Rules about Instruction}

The instruction concept that the teacher revealed in his climate change classes was 'preparing SSI-STEAM classes that fit the students' level'. The teacher had previously attempted to teach ssi classes with middle school students, but he had not realized that it might be difficult for them. He had aimed to learn about the interests his students had about different issues and he wanted to have his students make rational decisions considering ethical perspectives. However, the class was not successful because the students had a hard time 
TABLE 5 Images, principles, and rules about instruction

Image about instruction: Preparing ssi class tailored to students' level

\begin{tabular}{ll}
\hline Principle 1 & Teach so that students can understand easily \\
Rules & - Provide a variety of examples. \\
& - Explain using a metaphor. \\
- & Organise what they learned last time. \\
Principle 2 & Communicate with students \\
Rules & - Allow various answers through open questions. \\
- & Provide an opportunity for students to present the results of their \\
& activities. \\
- & Continuously respond to students' individual questions during \\
& the group activity time.
\end{tabular}

organizing their thoughts. Therefore, the teacher decided that it was important to organize classes according to the students' level because the content of the climate change class, with its multi-disciplinary approach, could be difficult for middle school students.

I've had an ssi class before. It was for the second year of middle school, and most of the students found it difficult. So, I thought it might be difficult to apply it to middle school students. [2nd Post-program interview]

The teacher described his class as an 'ssi class tailored to student levels' based on his belief that an easily understood and friendly class is a good class. The principles and rules related to this concept are shown in Table 5 .

The first principle that the teacher had for ssi classes tailored to the students' level was 'Teach so that students can understand easily'. He stressed that students were most satisfied with the class when the concept had been explained step by step in the science class to make it easier for them to understand.

Children love lecture-style classes. Students like to have examples that they hardly understand explained to them step by step. Or well-organized study sheets, things like that. [Pre-program interview]

The teacher's principle of prioritizing students' understanding has been embodied as 'Provide a variety of examples', such as 'Explain using metaphors', 
and 'Organize what they learned last time'. The teacher guided the students' activities with sticker examples as shown in Figure 7 and he had students compare the differences in weather and climate to mood and character, as shown in Figure 8.

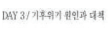

\section{기후위기 스티커 만들기}
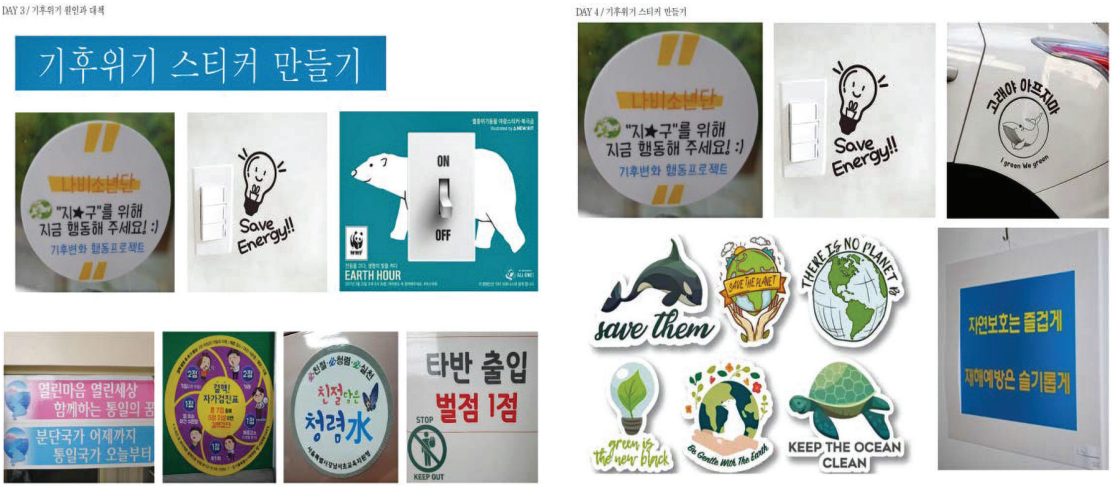

FIGURE 7 Examples of stickers about climate crisis developed by students
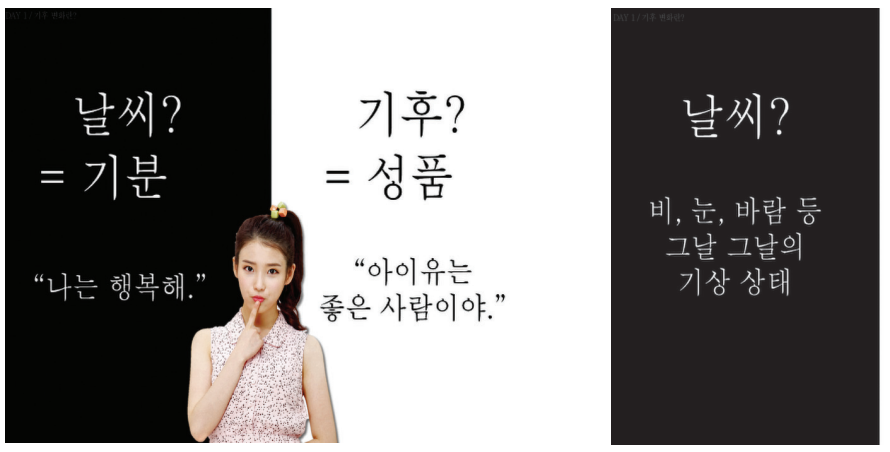

$$
\text { 기후? }
$$

30년 간

날씨의 평균

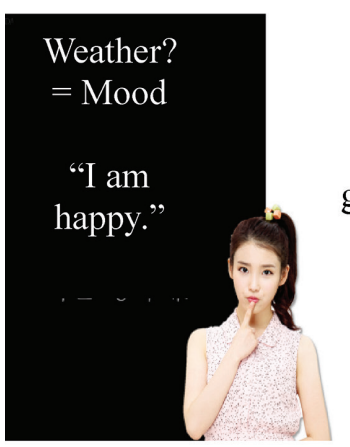

\section{Climate?}

$=$ Character

"She is a good person."

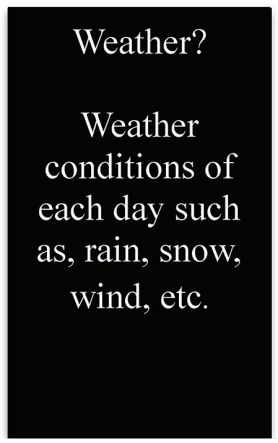

Climate?

Average of weather over a period of 30

years.

FIGURE 8 Teacher's PPT on difference between weather and climate, using metaphor 
To provide classes tailored to the students' level, he also continued to ask questions to let them express their ideas and opinions, on the principle of 'communicate with students'.

If I only talk all day in class, the students won't sympathize, only listen to and understand. If I want to have a memorable class, I definitely need to get them to speak or write on their own. [1st Post-program interview]

The teacher mentioned that students would only learn the class content, but would not have their own feelings about it, if he only used explanation. He realized the importance of students' feelings and sympathy/empathy rather than his one-sided explanation or lecture and created an environment in which students could express their ideas and feelings frequently. This principle was embodied in the three rules: 'Allow a variety of answers by posing open questions', 'Provide an opportunity for students to present the results of their activities', and 'Continuously respond to students' individual questions during the group activity time'.

\subsubsection{Images, Principles, and Rules concerning the School Milieu}

The participant teacher's concept of the school milieu was a 'cooperative and comfortable school environment'.

My fellow teachers cheered me for participating in the research, and they said, "Wow, that's great!" A homeroom teacher who is in charge of the class that participated in this study was always there to help me. [Pre-program interview]

Since he felt he had been receiving a lot of consideration as a first-year teacher, this participant teacher was grateful to his teacher colleagues. He said that there was a lot of encouragement and cooperation from teachers around him when he informed them of his participation in the research for this study. When the class hours seemed to be not enough due to school-wide events, he was able to get more class hours with the help of fellow teachers. Many teachers provided favors, helped, and generally cooperated with him. The principles and rules that embody the image of a 'cooperative and comfortable school environment' that the participant teacher has mentioned are as shown in Table 6 .

The first principle of practice based on the image of a cooperative and comfortable school environment was 'Prepare for the class in cooperation with fellow teachers'. Recognizing that there was a small quarrel between students in the climate change class, the teacher decided to get some advice from the homeroom teacher on how to manage the class more smoothly. 
Image about school milieu: Cooperative and comfortable school environment

$\begin{array}{ll}\text { Principle } 1 & \text { Prepare for the class in cooperation with fellow teachers. } \\ \text { Rules } & - \text { Form a group after discussing with the homeroom teacher } \\ & - \text { Prepare a science class with an experimental assistant teacher. } \\ \text { Principle 2 } & \text { Use the science lab to teach classes. } \\ \text { Rules } & - \text { Arrange desks according to class. } \\ & - \text { Install the necessary programs and devices for the class. } \\ - & \text { Pre-set the items needed for the class in the science preparation } \\ & \text { room. }\end{array}$

When we assigned group members in class, it was important to check with the homeroom teacher and see which children had problems. [1st Post-program interview]

I thought I wanted to emphasize to my students that I have to make this effort in response to climate change, and that it's very important. [Pre-program interview]

This principle is embodied in two rules. The first rule is 'Form a group after discussing with the homeroom teacher'. The participant teacher had grasped the relationship among students after consulting with a homeroom teacher and then grouped them according to her advice. This was necessary because smooth discussions and activities would be difficult to achieve if the students who often fought were in the same group.

The second rule is, 'Prepare a science class with an assistant teacher for the science lab'. Similarly, the second principle of practice based on the image of a cooperative and comfortable school environment is 'Use the science lab to teach class'. The participant teacher had a sense of psychological stability in the science lab space. This principle was further embodied in three rules: 'Arrange desks according to class', 'Install the necessary programs and devices for the class' and 'Pre-set the items needed for the class in the science preparation room'.

\subsubsection{Images, Principles, and Rules on Curriculum and Subject Matter}

The image or concept of the curriculum and subject matter held by the teacher was divided into two types: (1) climate change associated with various subjects and (2) personal action to cope with climate change. Judging that climate 
change was linked to multiple disciplines, the teacher tried to fuse a variety of subjects in his teaching. In addition, he had a perception that personal action was more important than social action to cope with climate change.

The participant teacher recognized that if the topic of climate change was related to many subjects and if the aim was action-oriented classes to respond to these topics, it would be effective for students to learn first from academic aspects of climate change, to further understand and act on climate change challenges. Therefore, climate change was organized and implemented with the image in mind that it is associated with multiple subjects, and on the basis that it has an inter-disciplinary character. He also stressed the importance of individual citizens recognizing the seriousness of climate change and making efforts to implement action against it on a personal level. The principles and rules based on these two images are summarized in Table 7 .

TABLE 7 Images, principles, and rules about curriculum and subject matter

Image for curriculum and subject matter:

1) Climate change associated with various subjects

Principle 1

Rules

Image for curriculum and subject matter:

2) personal action to cope with climate change

Principle 1

Recognize the importance of personal efforts to cope with climate change.

Rules

- Use the video of 'Birth of the Tragedy of Commons'.

- Calculate the amount of carbon dioxide emitted by households through the management fee notice.

Principle 2 Provide opportunities for personal action to cope with climate change.

Rules

- Produce and attach stickers on climate crisis.

- Guide students on examples of personal efforts that can be practiced at home. 
In addition to climate change covered by science subjects, climate change is often taught in other subjects. In technology and social studies, I thought, it's important to know how to talk about climate change. If students are interested in the issue of climate change, they'll be able to develop a variety of abilities by looking at what's covered in other subjects. "The Tragedy of the Commons" is linked to social studies. The activity of making climate crisis stickers is linked to art. [1st Post-program interview]

The principle to be taught by fusing different subjects is embodied in three rules: 'Explain the concept of the greenhouse effect, jet stream, and global warming', 'Discuss how the community can solve the problems of the sharing economy', and 'Make a climate crisis sticker considering the four elements of mark design'. The PPT depicting these rules revealed is similar to Figures 9, 10, and 11. Figure 9 is part of a teacher's PPT data explaining the type of greenhouse gas arising from the strengthening of jet streams due to global warming.

Figure 10 shows the video clips that students watched to find clues to solving the community problem called 'the climate crisis'.

Figure 11 is a worksheet that allows students to describe the purpose of making stickers, how to draw sticker designs, and where to attach them.

The first principle based on the image of 'personal action' was 'Recognize the importance of personal efforts to cope with climate change'. The participant teacher thought that personal efforts such as saving energy and resources, using eco-friendly products, recycling waste, and planting and growing trees, were most important to cope with climate change.

I wanted not just to convey scientific knowledge in climate change class, but to give a new message to students. And personally, it's important to take action in response to climate change. It's important for you to be aware of it. [1st Post-program interview]

This principle is shown in two rules of practice: 'Watch and discuss "The Tragedy of the Commons," and 'Calculate the amount of carbon dioxide emitted by households through management fee notice'. Based on electricity and gas usage to produce the fee notice they received last month, the teacher calculated with his students the number of pine trees that had to be planted to get rid of $\mathrm{CO}_{2}$ emissions, and measured $\mathrm{CO}_{2}$ emissions using a carbon footprint calculator, as shown in Figure 12. 

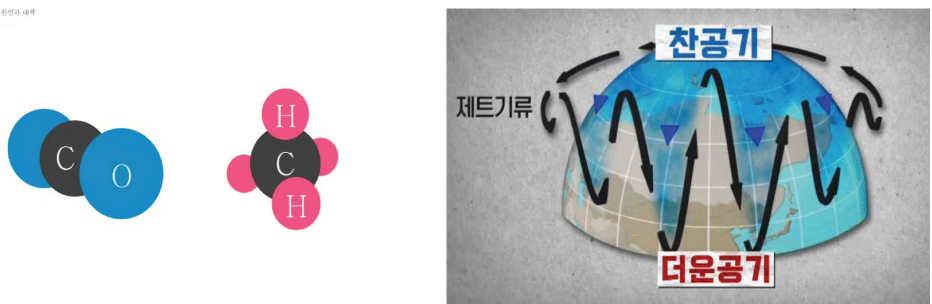

FIGURE 9 Teacher's PPT describing greenhouse gases and jet stream
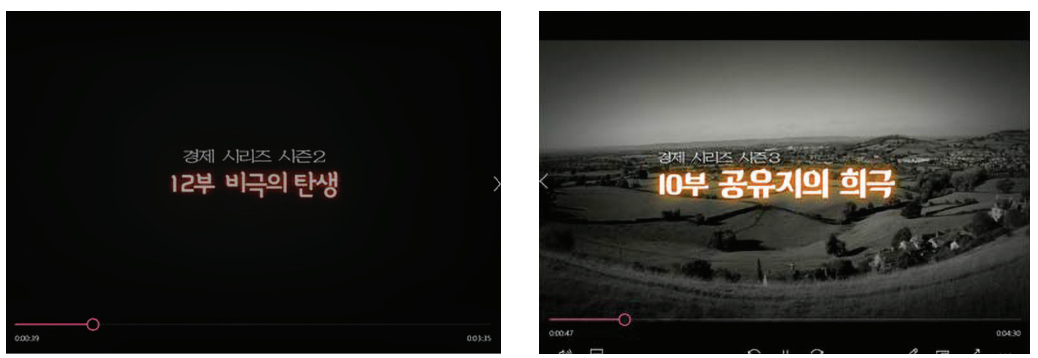

FIGURE 10 'Birth of Tragedy' and 'Comedy of the Commons' video clips

\begin{tabular}{|c|c|}
\hline 시안서 & 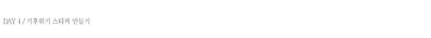 \\
\hline 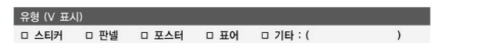 & 기후위기 스티커 만들기-마크 디자인 4 요소 \\
\hline 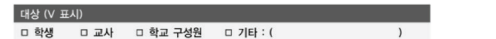 & 1. 상징성 : 주제(내용)을 잘 나타내야 한다. \\
\hline 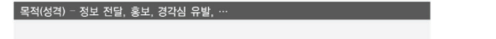 & 2. 단순성 : 간결하여 내용의 전달이 빨라야 한다. \\
\hline 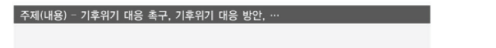 & 3. 주목성 : 눈에 잘 띄어야 한다. \\
\hline 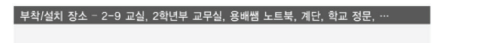 & 4. 독창성 : 개성이 드러나야 한다. \\
\hline 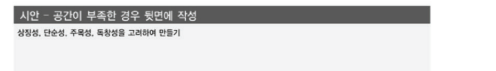 & $\begin{array}{l}\text { 기후변화 대응센터 - } \\
\text { https://bit.ly/34wSTVa }\end{array}$ \\
\hline Tentative Plan & \\
\hline $\begin{array}{l}\text { Type (v check) } \\
\square \text { sticker } \square \text { panel } \square \text { poster } \square \text { watch word } \square \text { etc: }(\quad)\end{array}$ & $\begin{array}{l}\text { Day 4/ Developing climate stickers } \\
\text { Developing climate change sticker- } \\
\text { Four elements of mark design }\end{array}$ \\
\hline$\square$ students $\square$ teachers $\square$ school members $\square$ etc: ( ) & $\begin{array}{l}\text { 1. Symbolism: The subject (content) must be } \\
\text { well represented. }\end{array}$ \\
\hline $\begin{array}{l}\text { Objectives (character) - information transfer, promotion, } \\
\text { triggering alertness,... }\end{array}$ & $\begin{array}{l}\text { 2. Simplicity: It should be concise and convey } \\
\text { the content quickly. }\end{array}$ \\
\hline $\begin{array}{l}\text { Subject (content) - call for responses to climate crisis, } \\
\text { countermeasures for climate crisis, ... }\end{array}$ & 3. Attention: It must be clearly visible. \\
\hline $\begin{array}{l}\text { Place of attachment - classroom, teacher's office, teacher's } \\
\text { notebook, stairs, school entrance, }\end{array}$ & 4. Creativity: Personality must be revealed. \\
\hline $\begin{array}{l}\text { Tentative plan - If you need more space, write on the back. } \\
\text { Consider symbolism, simplicity, attention, creativity when } \\
\text { developing. }\end{array}$ & $\begin{array}{l}\text { Climate change response center - } \\
\text { https://bit.ly/34wSTVa }\end{array}$ \\
\hline
\end{tabular}

FIGURE 11 Teacher's PPT introducing climate crisis sticker planning and designing 


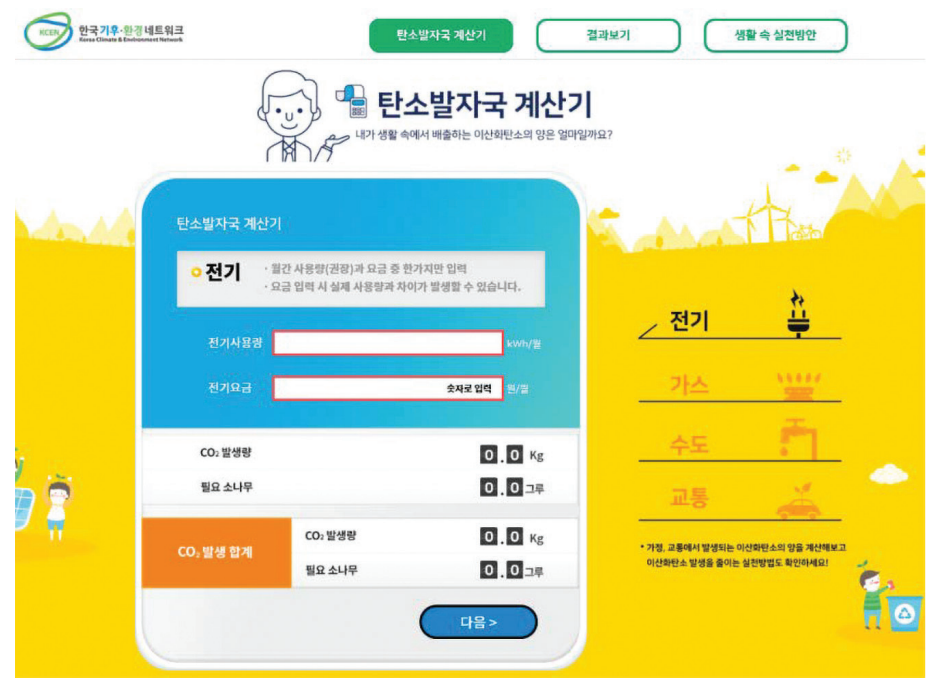

FIGURE 12 Online carbon footprint calculator

I wanted to give students who are not aware of the climate crisis and are passive, the opportunity to put stickers actively. They can make social movements in schools by attaching stickers. It's one of their personal action plans, so I wanted my students to start doing small things'. [1st Post-program interview]

The principle of providing opportunities for personal action turned out to be the rule of 'Making and attaching climate crisis stickers' in class. Students actively participated in the activities to publicize the seriousness of climate change, and to produce stickers campaigning for the reduction of carbon dioxide, attaching the stickers to their intended locations.

\subsubsection{Orientation \\ 6.1.2.1 Experiential Orientation}

As a first-year teacher, the participant teacher considered his teaching experiences while at university to be an important factor that influenced his classes a lot and developed his own knowledge.

The decisive reason for becoming a teacher was due to my club experience during my university. I joined the educational volunteer club for three years. I became the president of the club, and I thought a lot while I was in the club. And in the club, I wanted to try to teach different subjects because I thought I could study physics at any time because 
it was my major. The first class I taught was related to law. The second class was passwords and math. The third class was English. The fourth class was music. The last, fifth, was the Common class, the social studies subject I told you about. [Pre-program interview]

Through club activities, he was able to get the opportunity to examine and study many areas by organizing classes in subjects such as mathematics, English, social studies and music, even though they were not his major. In the process, he realized that even though each subject had the same topic, each subject set different teaching goals to convey the content to the students. He also had a positive perception of the curriculum convergence class, knowing that fusing different subjects under one topic will help students understand the topic better; approaching the learning subject in different ways gives students a wide range of thought and career perspectives. This experience has led him to integrate social studies and art subjects with the teaching of climate change. Even if pre-service teachers learn a variety of educational theories and major knowledge at the College of Education, it is quite another dimension to teach students in the field. Unexpected situations may occur among students or between students and teachers, which may lead to conflicts in the classroom. This teacher had accumulated these experiences from university and was able to broaden his view of teaching by taking non-major classes, which had a positive impact on his teaching in an actual school.

\subsubsection{Social Orientation}

The participant teacher felt the need for a new classroom direction incorporating diverse experiences. He had a chance to reflect on his class after hearing a parent's opinion during the teacher assessments process. The parent wanted his child to experience other classes in addition to the usual school science classes. The teacher concluded that he needed to use a variety of teaching methods and introduce a choice of science-related content sourced from outside the usual textbooks. These strategies could make students get more interested in science, he thought, even if there were gradual changes in teaching methods. He also had the positive perception that he wanted to try to introduce a process-oriented evaluation through new teacher training. He expressed his intention to try a course-oriented evaluation next year because he saw course-oriented assessment as a new paradigm that did not separate the learning process from evaluation. From attending in-service training and online lectures, the teacher also felt that it was necessary for science education to allow students to express their opinions on issues in modern society and further put them into action based on the new knowledge they had acquired. 
At the junior high school level, it's important to know what's going on around students, in our country, and around the world. I think it's especially important to have a voice around the world these days, as is required in this class. Therefore, I think there is a need for an action-oriented climate change class. [Pre-program interview]

The teacher, a first-year teacher, was forming a social orientation drawing from diverse influences, including in-service teacher education, online lectures, teacher evaluations, and learning communities of fellow teachers. As he understood that the natural flow of education goes beyond just a learner-oriented class that is interested merely in exploring and learning scientific knowledge, he agreed that students also need education as citizens of a democracy: in other words, they need to acquire scientific knowledge of science-related social issues and make decisions as well as act on the right value judgments. That was his motivation for carrying out the action-oriented climate change SSI-STEAM class.

\subsection{Teacher's Conflicts with the SSI-STEAM Climate Change Education Program}

6.2.1 Why Politics in Science Classes?

In the process of collaboratively revising the initial program, the participant teacher had an internal conflict between his perception of the nature of science classes and the political nature of climate change issues. The teacher had a belief that his science class had nothing to do with politics. He tried to take a neutral stance, judging that teachers' thoughts could be injected into middle school students whose values have yet to be established, even if students were asked for their political opinions. However, in the process of implementing the program and learning about all the interests related to climate change, the teacher realized that there were different political perspectives surrounding climate change.

The teacher finally included former US President Donald Trump's Twitter 'tweet' in the program (Figure 13) to let the students know that there were some people who display denial of climate change. This also allowed students opportunities for discussion for and against the existence of climate change and raised students' willingness to respond to climate change. He changed his position from neutral science teaching to a politicized science class because of the urgency and importance of the climate change issue. In addition, because climate change encompasses many interests, depending on social affiliations and groups, he came to realize that students needed to know about the 
In the beautiful Midwest, windchill

temperatures are reaching minus 60 degrees, the coldest ever recorded. In coming days, expected to get even colder. People can't last outside even for minutes. What the hell is going on with Global Waming? Please come back fast, we need you!

\section{오후 6:28 - 2019년 1월 28일}

49,468 리트윗 195,547 마음에 들어요

\section{8,166 โ】 $49,468 \bigcirc 195,547$}

FIGURE 13 Donald Trump's Twitter 'tweet' used in class

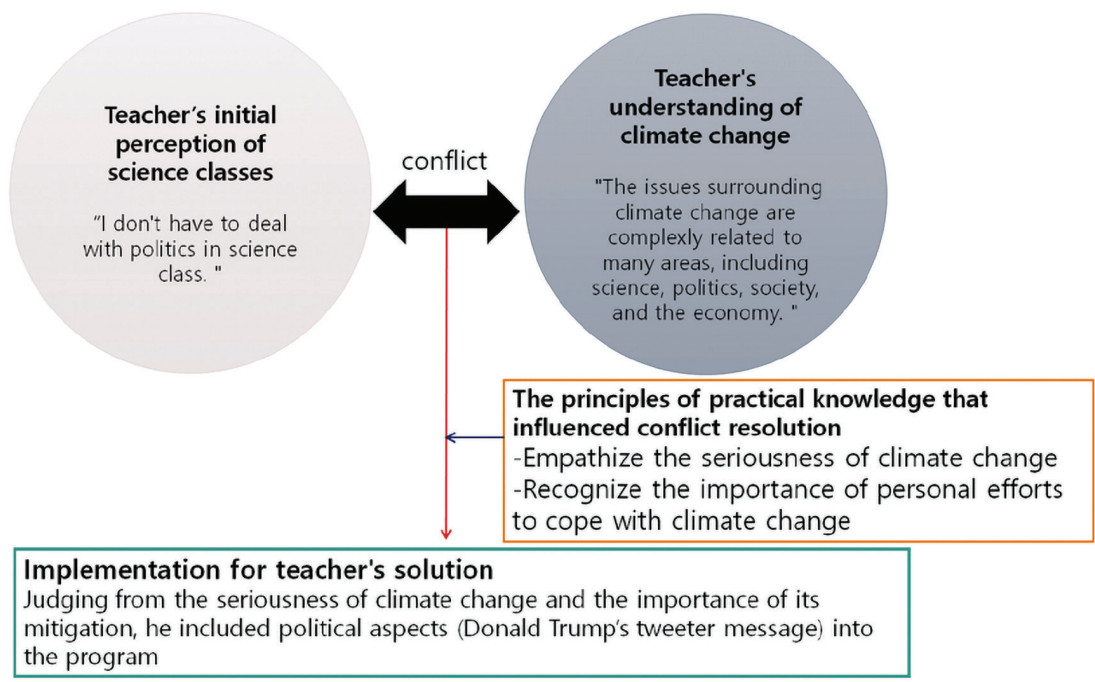

FIGURE 14 A conflict on including politics in science class and the teacher's resolution

various political positions on the issue. As a result, the teacher introduced political material, a tweeter message by the President Trump, into the class. The teacher's judgment and implementation in the process of resolving these conflicts were influenced by the practical knowledge that teachers should guide and lead students to understand the seriousness of climate change, and that personal practice is particularly important in responding to climate change. So, to sum up the conflict and the resolution process (see Figure 13). 


\subsubsection{Too Many Activities in Limited Class Hours}

The teacher had difficulty in conducting the class due to the constraints of time. Initially, six class hours were available for the program. However, after reviewing the program he realized that they were not enough, and he tried to secure one more class hour by asking for other teachers' help.

Judging that the six class hours were not enough to deal with a lot of content even before the class, he asked another teacher and changed the class time to seven class hours. In addition, he tried to use the science lab to make the most of the given class time. However, it was nearly the end of the academic year, and the class hour had been reduced from 45 minutes to 40 minutes because of school-wide events. Students who participated generally spent more time writing reports than expected in the group activities of the Climate Change Headquarters. This made it difficult for the teacher to implement the program.

The biggest thing on my mind was ... The environment has suddenly become a burdensome environment rather than the burden of the research class itself because the class hours are going to be reduced, and students can't have a class in the afternoon, and they have to practice for the choir competition. I wanted to have a class for about two weeks, but I suddenly had to do it in about a week. I was most worried about what I would do if I couldn't finish all the stories and activities that I wanted to do in class. [Pre-program interview]

Due to the limitations of class time, the teacher had conflict in implementation. Action-oriented climate change classes not only teach students about the causes and effects of climate change, but also provide them with opportunities to respond with action after researching ways to cope with climate change. In addition, it took a lot of time for students to take the initiative in exploring issues and produce results by linking climate change issues with STEAM education activities. While listening to and responding to students' opinions on climate change, the aim was to seek scientific solutions to climate change, and interaction with the students also took a long time. It was from this process that the teacher's conflict emerged, as summarized in Figure 15.

The teacher could not resolve this conflict and tried instead to proceed with the class quickly, in the planned order. In the process, teacher-led explanations and suggestions became the center of the class rather than students discussing each other's opinions and exchanging opinions in the community's discussion activities on how to resolve climate change, after watching the 'Tragedy and Comedy of the Commons' videos. In addition, the teacher showed a lot of regret for not interacting with the students throughout the class. 


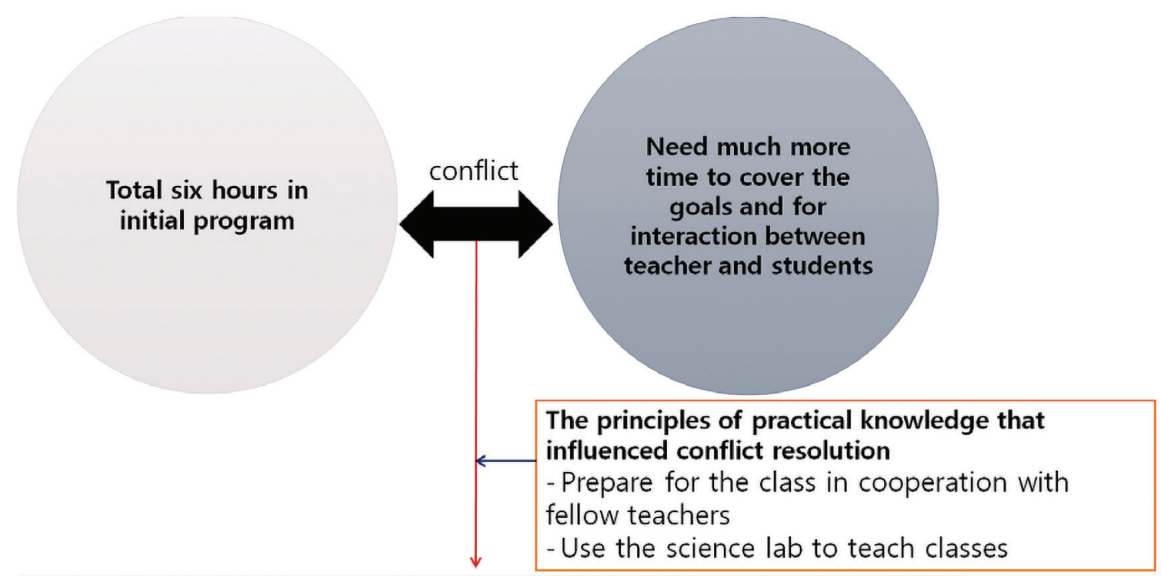

Implementation for teacher's solution

Secure one more class hour (total seven hours) with the cooperation of fellow teachers. Use science labs for more interaction among teacher and students

FIGURE 15 Conflict about class hours and the teacher's resolution

This study was conducted on the premise that exploring teachers' practical knowledge can provide the most in-depth look into teachers' practice. Therefore, we were able to look closely at how the teacher organized the climate change class and how he led the action of the students in the actionoriented class, using his practical knowledge. This is meaningful in that, unlike previous studies that have so far explored only some aspects of science teachers' practical knowledge, we have analyzed teachers' practical knowledge indepth according to the criteria of orientation, content and structure, in the context of the SSI-STEAM climate change education program, and we have looked at any conflicts between these criteria. In addition, we expect that this study, which examines the practical knowledge of a novice teacher, will serve as the first step in narrowing the gap between pre-service teacher education and school sites for SSI-STEAM education. The conclusions of the study are below.

First, the participant teacher constructed SSI-STEAM climate change program classes, influenced by his experiential orientation based on three years of university volunteer club activities, and by the social orientation of recognizing the need for action-oriented classes through teacher evaluation, teacher training, and lectures. The teacher's practical knowledge in each content area can be described by structure. The teacher showed student-centered practical knowledge in his self-knowledge, holding an image of himself as a guide, and 
in his instruction knowledge, with an image of teaching tailored to students' levels. The teacher's practical knowledge of the content of both the curriculum and subject matter allowed him to adapt these elements to the theme of climate change, using the images of inter-disciplinary convergence and individual action to solve climate change. In terms of the content of school milieu of knowledge, the image the teacher held was a 'cooperative and comfortable school environment'.

Second, the teacher expressed a conflict between his belief in the science class and climate change class goals in the process of constructing the climate change class but was able to organize the class and resolve the conflict in a way that could foster students' personal will to cope with climate change, influenced by his practical knowledge. In addition, a conflict emerged between the need for continuous interaction with the students and the goal of finding a direction for action to respond to climate change in the context of the limited class time available. The teacher tried to secure more class time by utilizing his practical knowledge, but he was not able to continue to interact with the students or explore deeply enough with them the measures available to cope with climate change.

As teachers' practical knowledge is constructed by teachers in the context of their work, practical knowledge integrates experiential knowledge, formal knowledge, and personal beliefs (van Driel et al., 2001). Therefore, practical knowledge is thought to be formed and accumulated through many years of teaching experience (Beijaard \& Verloop, 1996), and emerging teachers' practical knowledge is considered to be hardly developed. Expert and novice teachers do not only differ in the amount of knowledge they possess but also and foremost in the way this knowledge is organized in their memory (Beijaard \& Verloop, 1996). The knowledge of expert teachers seems to be better or more thoroughly integrated than the knowledge of novice teachers (Sternberg \& Horvath, 1995). A study on the practical knowledge of student-teachers seems to support the difference between expert and novice teachers. Ratinen et al. (2015) investigated primary student-teachers' practical knowledge and reported that student-teachers knew the appropriate teaching strategies even for dialogic teaching, but they did not know how these should be enacted in the classroom. This can be interpreted to mean that the student-teachers have theoretical knowledge learned from pre-service education, but they still need more experience to develop practical knowledge to enact such knowledge in their teaching. However, other studies on the practical knowledge of emerging teachers have reported different results.

Yu et al. (2010) explored the practical knowledge of two secondary science teachers with three and six years of teaching career behind them, respectively. 
The two teachers developed their own practical knowledge depending on the weighting of their main concerns, a weighting which conformed with their life contexts. This study also explored the practical knowledge of a teacher with even less experience, in the first year of teaching. The results of this study show that even beginner teachers develop their own practical knowledge and adapt it to the new teaching context. The development of new teachers' practical knowledge may depend on the school contexts as well as individual characteristics. In both Yu et al. (2010) and in this study, the new teachers described had attended large urban schools in Korea. These schools usually have more classes in each grade-level, and the teachers in such schools tend to teach a small number of subjects to many classes in each academic year. This means that they tend to repeat teaching the same lesson several times, and therefore have more intensive experience with the subject matter, albeit within a limited time. On the other hand, teachers in a small school usually teach many subjects to a small number of classes and have only moderate opportunities to teach each subject even though they have had longer careers.

The SSI-STEAM climate change education approach is a new teaching approach with an unfamiliar theme, and may pose big challenges to teachers. It may be difficult to identify the change in a teacher's practical knowledge in new contexts without having information about his/her practical knowledge in normal science classes. Based on the review of the results of the study, some of the practical knowledge seems to be stable across different contexts, while others may be more context-specific. Examples of stable practical knowledge are the participant teacher's image of self-knowledge as a guide, instruction as teaching tailored to students' levels, and the school milieu as a cooperative and comfortable school environment. The teacher may show such practical knowledge while teaching for most of his/her class. On the other hand, some practical knowledge related to curriculum and subject matter seems to be more context-specific, such as images that climate change is associated with various subjects (inter-disciplinary) and that personal action is important to cope with climate change. With his practical knowledge, the teacher in this study could deploy resources such as 'The Tragedy of Commons', sticker design drawn from social studies and art, and develop an inter-disciplinary program.

In the field of conflict resolution in schools, minor distractions and disturbances are conflicts (Hakvoort, et al., 2020). Among the different ways to understand an emerging conflict in the classroom, the conflicts seen in this study can be categorized as a challenge of agenda, i.e., conflicts in content teaching. The conflicts of the teacher in this study, between belief in his science class and lack of time, can be categorized under knowledge of content (curriculum and subject matter) within practical knowledge. Considering 
the participant teacher's implementation of the SSI-STEAM program, which includes activities of inquiry, investigation and action within six class hours, securing time was absolutely essential. The teacher managed to find one more class hour thanks to the cooperation of his colleagues. He also reserved a science laboratory for the program to save preparation time. Another conflict between the teacher's belief that there should be no politics in science classes and the action-oriented SSI-STEAM program could be attributed to the different nature of the two areas. When science teachers try to introduce actionoriented ssi classes, many of them may also experience this conflict. Conflicts may induce difficulties for teachers to resolve but they also provide teachers with opportunities to use their practical knowledge to resolve, and to develop their practical knowledge to a higher level. In this study, the teacher resolved the conflicts either by using his practical knowledge or by changing his belief and introducing political aspects that could encourage students to discuss climate change.

\section{8}

\section{Implications}

From the findings of this study, the following implications are suggested. First, teaching experience of and training in SSI and STEAM education should be provided during pre- and in-service education. The participant teacher in this study could develop and implement lesson plans by fusing various subjects from his extra-curricular experiences, not from theoretical background acquired in teacher education courses. Action-oriented SsI and STEAM education are strange to many teachers and expected to present many challenges to them. The participant teacher joined in this study to experience and learn about the action-oriented ssi teaching approach. Therefore, SSI and STEAM education need to be included in pre- and in-service education programs.

Second, it is necessary to create an environment where pre-service science teachers can be exposed to diverse teaching experiences, such as mentoring college students and working with community-linked educational services. First-time teachers often have no actual teaching experience in schools except for teaching practice. However, during teaching practice, there are not enough opportunities for pre-service science teachers to gain experience in organizing and conducting classes. In this study, the participant teacher had experiences in teaching many different subjects through three years of educational volunteer club activities at his university. This had significant impacts on his ability to teach climate change classes in terms of finding learning resources and 
planning lessons. Therefore, it is necessary to increase extra-curricular opportunities for pre-service science teachers, such as community-linked education services and mentoring peer students.

Third, teachers' learning communities need to be encouraged to share and develop their practical knowledge. Teachers' practical knowledge develops while teaching in the field, but they often fail to share such knowledge due to school culture and administrative work. The participant teacher in this study had collaborated with other teachers in organizing and managing classes, but hardly found any colleagues with whom he could share and discuss the climate change lesson plans. If teachers with a range of careers gather to share and discuss their ideas, based on their practical knowledge, then career teachers and new teachers can grow together.

Fourth, even though this study has some limitations, such as detailing only a single case, only a seven-hour class period, a single context (SSI-STEAM), and a lack of international comparison because of the Covid-19 pandemic, the participant teacher's practical knowledge was identified and described comprehensively based on his experience, beliefs, and school contexts. Exploring a science teacher's practical knowledge in terms of orientation, structure, and content (Elbaz, 1981, 1983) in a new context was useful and informative. Considering the complexity and personal context-embedment of teachers' practical knowledge (de Vries \& Beijaard, 1999), much more empirical research is needed in this area. Further research is needed to understand how teachers' practical knowledge and students' learning are related.

\section{Abbreviations}

IPCC Intergovernmental Panel on Climate Change

PCK Pedagogical Content Knowledge

SSI Socioscientific Issues

STEAM Science Technology Engineer Arts Mathematics

SSI-STEAM Socioscientific Issues and Science Technology Engineer Arts

Mathematics

\section{Acknowledgements}

Thank you for teachers and students in Korea and Australia who participated in this study. 


\section{Funding}

This study was supported by the Australian Government's Department of Foreign Affairs and Trade (Australia-Korea Foundation, AKF Grant 2018040) and by the National Research Foundation of Korea (NRF) grant funded by the Korea government (MOE). (No. 2019S1A5A2Ao3O48062).

\section{Ethical Considerations}

Approval to conduct this study was granted by the Seoul National University Ethics Review Board. The data collected from this project has obtained the necessary clearance from the school, guardians, students and the teacher involved in the study. The names of the school and participants used in this study are all pseudonyms. Any photos and images appearing in this paper were provided with permission of the participant.

\section{About the Authors}

A-Rang Won is a science teacher in secondary school and a graduate student in Science Education in the Earth Science Education department at Seoul National University in Seoul, Republic of Korea. Her research focuses on exploring teachers' practical knowledge in action-oriented climate change SSI-STEAM classes. She is especially interested in how teachers reconstruct and interact with the surrounding environment and lead the class with what beliefs and knowledge they have in action-oriented classes. She is also interested in teacher education, which affects how teachers organize and lead classes in a new context.

Su-Yeon Choi is a science teacher in secondary school and a graduate student in Science Education in the Earth Science Education department at Seoul National University in Seoul, Republic of Korea. Her research focuses on climate crisis education at junior high school level. She is particularly interested in cultivation of climate literacy from new forms of climate crisis education such as convergence of ssi education and STEAM education. And she is also interested in educating students to have their own ability to act on climate crisis issues. 
Hye-Eun Chu is a senior lecturer in science education at Macquarie University in Sydney, Australia. Before joining Macquarie University she was an assistant professor in science education at Nanyang Technological University, Singapore, post-doctoral research fellow at Curtin University, Perth, Western Australia, and lecturer and researcher at Dankook University, Young-In, Korea. Her research interests include the investigation of students' conceptual development in science learning in arts integrated STEAM contexts.

Hyun-Jung Cha is a lecturer in the Earth Science Education department at Seoul National University and in the Science Education department at Seoul National University of Education in Seoul, Republic of Korea. She received her bachelor's degree in Earth Science Education and master's degree and doctor's degree in Science Education from Seoul National University in the Republic of Korea. Her research focused on modeling-based science learning, authentic inquiry, and science teacher expertise. She is particularly interested in providing students with opportunities for earth science learning dealing with actionoriented Socio-Scientific Issues such as climate change.

Hyeonjeong Shin is a science teacher in secondary school and a doctoral student in the Department of Earth Science Education at Seoul National University in Seoul, Republic of Korea. She is interested in science learning as intra-action with materials in informal environments and explored science learning through interaction with learning affordance of exhibitions at a science center in her master's thesis. Another central theme of her research is the integrated curriculum of climate change education in schools and youth action for climate change.

Chan-Jong Kim is a Professor in the Department of Earth Science Education at Seoul National University in Seoul, Republic of Korea. He holds a bachelor's degree in Earth Science Education and master's degrees in Geological Sciences from Seoul National University in the Republic of Korea. He also holds doctoral degree in Science Education from University of Texas at Austin in the United States. His research focuses on scientific modeling as an approach to scientific exploration and learning in a variety of subjects, contents, and contexts and on development and application of various methods for the analysis of collective talk with learning of science. Also, He is particularly interested in education for diverse learners in Korean K-12 on global environmental risks such as climate change. 


\section{References}

Bayram-Jacobs, D., Henze, I., Evagorou, M., Schwartz, Y., Aschim, E. L., AlcarazDominguez, S., Barajas, M., \& Dagan, E. (2019). Science teachers' pedagogical content knowledge development during enactment of socioscientific curriculum materials. Journal of Research in Science Teaching, 56, 1207-1233.

Beck, U. (1997). Risk society: Toward a new modernity (S.-T. Hong, Trans.). Saemulgyul. (Original work published 1986).

Beijaard, D., \& Verloop, N. (1996). Assessing teachers' practical knowledge. Studies in Educational Evaluation, 22(3), 275-286.

Choi, K. H., Cho, H. H., \& Kim, J. H. (2000). The effects of ethical education in science classes on middle school students' attitude toward science. Journal of the Korean Association For Science Education, 20(4), 642-651.

Clandinin, D. J. (1985). Personal practical knowledge: A study of teachers' classroom images. Curriculum inquiry, 15(4), 361-385.

Connelly, M. F., Clandinin, D. J., \& He, M. F. (1997). Teacher personal practical knowledge on the professional knowledge landscape. Teaching and Teacher Education, 13(7), 665-674. doi:10.1016/So742-051X(97)ooo14-o.

Cross, R. T., \& Price, R. F. (1996). Science teachers' social conscience and the role of controversial issues in the teaching of science. Journal of Research in Science Teaching: The Official Journal of the National Association for Research in Science Teaching, 33(3), 319-333.

de Vries, Y., \& Beijaard, D. (1999). Teachers' conceptions of education: A practical knowledge perspective on Good' teaching. Interchange, 30(4), 371-397.

Elbaz, F. (1981). The teacher's "practical knowledge": Report of a case study. Curriculum inquiry, $11(1), 43-71$.

Elbaz, F. (1983). Teacher thinking. A study of practical knowledge. London: Croom Helm.

Giddens, A. (2009). The Politics of Climate Change. (Hong, W. H., Trans.) Seoul: EcoLivres. (Original work published in 2009).

Hakvoort, I., Larsson, K., \& Lundstrom, A. (2020). Teachers' understandings of emerging conflicts. Scandinavian Journal of Educational Research, 64(1), 37-51.

Handal, G., \& Lauvas, P. (1987). Promoting reflective teaching: Supervision in practice. Milton Keynes: Open University Education Enterprises.

Intergovernmental Panel on Climate Change [IPCC]. (2014). Climate Change 2014 Synthesis Report: Summary for Policymakers. Geneva: IPCC.

Johnson, J., Macalalag, A. Z., \& Dunphy, J. (2020). Incorporating socioscientific issues into a STEM education course: exploring teacher use of argumentation in SSI and plans for classroom implementation. Disciplinary and Interdisciplinary Science Education Research, 2(1), 1-12. 
Kim, T. W., \& Lee, S. B. (2015). A technology teacher's practical knowledge in middle school's technology practice lesson. The Korean Journal of Technology Education, 15(3), 25-49.

Kim, Y. J., \& Hong, H. K. (2017). A case study for developing 'personal practical knowledge (PPK)' of pre-service chemistry teachers: based on the reflective discussion of community of practice (CoP) activity. The Journal of Korean Association for Research in Science Education, 37(2), 347-358.

Kind, V. (2009). Pedagogical content knowledge in science education: perspectives and potential for progress. Studies in science education, 45(2), 169-204.

Korean Foundation for the Advancement of Science and Creativity [KOFAC]. (2018). Good lesson with STEAM education: Teachers' guidebook. KOFAC.

Lee, H. J., \& Jang, H. S. (2011). Enlargement of pre-service science teachers' understanding of SSI teaching through a teacher education program. Journal of Research in Curriculum Instruction, 15(4), 913-932.

Lee, H., \& Witz, K. G. (2009). Science teachers' inspiration for teaching socioscientific issues: Disconnection with reform efforts. International Journal of Science Education, 37(7), 931-96o.

Lee, H., Abd-El-Khalick, F., \& Choi, K. (2006). Korean science teachers' perceptions of the introduction of socio-scientific issues into the science curriculum. Canadian Journal of Math, Science \& Technology Education, 6(2), 97-117.

Lee, S. K., Oh, P. S., Kim, H. R., Lee, K. H., Kim, C. J., \& Kim, H. B. (2009). A review of research perspectives on science teachers' pedagogical content knowledge and practical knowledge. Journal of Korean Teacher Education, 26(1), 27-57.

Lim, S. M., Kim, Y. S., \& Lee, T. S. (2014). Analysis of elementary school teachers' perception on field application of STEAM education. Science Education, 38(1), 133-143.

Lincoln, Y. S., \& Guba, E. G. (1985). Naturalistic inquiry. California: Sage.

Merriam, S. B. (1998). Qualitative research and case study applications in education: Revised and expanded from "Case study research in education.". San Francisco: Jossey-Bass Publishers.

Nilsson, P., \& Vikström, A. (2015) Making PCK explicit: Capturing science teachers' Pedagogical Content Knowledge (PCK) in the science classroom. International Journal of Science Education, 37(17), 2836-2857.

Ratinen, I., Viiri, J., Lehesvuori, S., \& Kokkonen, T. (2015). Primary student-teachers' practical knowledge of inquiry-based science teaching and classroom communication of climate change. International Journal of Environment \& Science Education, $10(5), 649-670$.

Sadler, T. D., \& Zeidler, D. L. (2005). Patterns of informal reasoning in the context of socioscientific decision making. Journal of Research in Science Teaching 42(1), $112-138$. 
Schneider, R. M., \& Plasman, K. (2011). Science teacher learning progressions: A review of science teachers' pedagogical content knowledge development. Review of Educational Research, 81(4), 530-565.

Shulman, L. (1986). Those who understand: Knowledge growth in teaching. Educational Researcher, 15(2), 4-14.

Shulman, L. (1987). Knowledge and teaching: Foundations of the new reform. Harvard Educational Review, 57(1), 1-23.

Son, M. H., \& Jung, D. H. (2019). Limits of STEAM education and its Improvement alternative: based on the viewpoints of STEAM expert teachers. Journal of the Korean Association for Research in Science Education, 39(5), 573-584.

Sternberg, R. J., \& Horvath, J. A. (1995). A prototype view of expert teaching. Educational Researcher, 24(6), 9-17.

Van Driel, J. H., Beijaard, D., \& Verloop, N. (2001). Professional development and reform in science education: The role of teachers' practical knowledge. Journal of Research in Science Teaching, 38(2), 137-158.

Yang, J. E., Kim, H. J., Gao, L., Kim, E. J., Kim, S. W., \& Lee, H. J. (2012). Perceptions of science teachers on socioscientific issues as an instructional tool for creativity and character education. Journal of the Korean Association for Research in Science Education, 32(1), 113-128.

Yu, E.-J., Lee, S.-K., Choi, J.-R., \& Kim, C.-J. (2010). Investigation on science teachers' practical knowledge by life history. Journal of Korean Association of Science Education, 30(8), 971-987.

Zeidler, D. L. (2016). STEM education: A deficit framework for the twenty first century? A sociocultural socioscientific response. Cultural Studies of Science Education, n(1), $11-26$.

Zeidler, D. L., \& Nichols, B. H. (2009). Socioscientific issues: Theory and practice. Journal of Elementary Science Education, 21(2), 49-58. 